\title{
Geological mechanisms of the accumulation of coalbed methane induced by hydrothermal fluids in the western Guizhou and eastern Yunnan regions
}

\author{
Shuling Tang ${ }^{\mathrm{a}}$, Dazhen Tang ${ }^{\mathrm{a}, *}, \mathrm{Hao} \mathrm{Xu}^{\mathrm{a}}$, Shu Tao ${ }^{\mathrm{a}}$, Song Li ${ }^{\text {a }}$, Yunguang Geng a \\ a Coal Reservoir Laboratory of National CBM Engineering Center, China University of Geosciences, Beijing \\ 100083, China. \\ * Corresponding author at: China University of Geosciences, Beijing 100083, China. Email address: \\ tang@cugb.edu.cn; Tel number: 86-010-82322011.
}

\begin{abstract}
Based on the geological characteristics of hydrothermal fluid in the western Guizhou and eastern Yunnan regions, this paper discusses the geological mechanisms of hydrothermal fluid on the coalbed methane (CBM) system. From the perspective of hydrothermal fluid activity in the regional strata, we analyze the geological processes by which coalbed methane is enriched and accumulated in this region. Our results demonstrate that two stages of regional thermal fluid activity occurred in the western Guizhou and eastern Yunnan regions. In the earlier stage, calcium fluid acted as the carrier, but in the later stage, it was replaced by siliceous fluid with a small amount of calcium fluid. The former resulted from thermal cycling of fluid through the strata, and the latter was caused by injection of deeply sourced high temperature fluids. We propose three geological mechanisms by which hydrothermal fluid affected coalbed methane accumulation: stimulation for hydrocarbon generation, transformation for physical properties and fluid supercharging. The hydrothermal fluid impels coalbed methane to generate and migrate at high intensity; it also produces dense swarms of tubular pores that coincide with tectonic stress. As a result, the coal body is broken, and there are changes to the porosity and permeability of the coal. Pressure development in the regional gas reservoir depends on the intensity of the fluid effect and the differential leakage of fluid pressure in the coal reservoir. The relatively closed and stranded hydrothermal fluid environment of coal measure strata tends to lead to a high pressure coalbed methane system. The platform uplift in northwestern Guizhou is one such environment, in which the geological configuration of the high temperature fluid provided favorable conditions for the enrichment and accumulation of coalbed methane.
\end{abstract}

Keywords: Hydrothermal fluid; Geological mechanisms; Coalbed methane; Enrichment and accumulation; Western Guizhou and eastern Yunnan regions; Geological configuration

\section{Introduction}

Western Guizhou and eastern Yunnan are part of an important region in China that has highly abundant coalbed methane(CBM) resources (Tian et al., 2008; Gao et al., 2009). Previous studies in the area have largely focused on describing the sedimentary environment and the coal accumulating characteristics of coal bearing strata, the origins of coalbed methane, the physical characteristics of the coal reservoir, and the evolution of heat accumulation; they have also evaluated potential coalbed methane resources (Gui et al., 1999; Tao et al., 2010; Li et al., 2014). Research has shown that the development of coal measure strata has unique geological features. Coal-bearing strata mainly occur in Longtan Formation, the Late Permian to Late Paleozoic. The tectonic evolution of these strata included multiphase development, strong differentiation and late stereotypia. The sediment has features indicative of interacting marine and terrestrial facies, ground plan divergence and frequent vertical change. These features lead to weak aquosity, varied coal strata and tectonic type of controlling gas. In addition, there is very high gas content, resource 
abundance, reservoir pressure and stress. Finally, there is large vertical variation in coalbed methane resources, coal rank and permeability and geologic conditions (Gu et al., 2002; Qin et al., 2008; Li et al., 2015).

Many researchers have shown that hydrothermal deposits are widely distributed in this area, suggesting that formation of hydrothermal fluids may have had a significant effect on the enrichment and accumulation of coalbed methane (Yang, 1982; Zhou et al., 2000; Song et al., 2005; Qin et al., 2008; Li et al., 2014). However, the mechanism by which hydrothermal fluids would affect the accumulation of coalbed methane has not been characterized. Hydrothermal fluids not only stimulate coalbed methane generating, but can also directly or indirectly control the storage capacity of the coal reservoir and the accumulation and dispersion characteristics of coalbed methane. They can also alter the dynamic balance of the CBM energy system via changes to the coal composition, thermal physics, and fluid pressure. Fluid inclusions contain geological and geochemical information that reflects the properties, composition, physicochemical conditions and geodynamic characteristics of the paleo-fluid in an ancient basin (Jones et al., 1977; Tobin and Claxton, 2000; Kelly et al., 2000; Marfil et al., 2002; Sun, 2003; Dubessy et al., 2004). In this study, we combine basin evolution simulation and fluid inclusion analysis to characterize hydrothermal fluid activity and discuss the contribution of hydrothermal fluids to the dynamic balance of the coalbed methane energy system. We also propose three mechanisms by which hydrothermal fluids affect the accumulation of coalbed methane. Taking into account the division between the areas of plutonic metamorphism and superposed thermal metamorphism in the western Guizhou and eastern Yunnan regions, we clarify the process and influencing factors of coalbed methane accumulation in this complex geological setting.

\section{Geologic setting}

The region spanning western Guizhou and eastern Yunnan Provinces is a famous coal industry base south of the Yangtze River. It is an ideal area for commercial exploration and development of industrial coalbed methane in China. Because of Yanshan and Himalayan movement, the region is divided into various intermontane downwarped and downfaulted basins. Following later tectonic movement, these prototypical basins were mostly destroyed. The preservation of some residual basins is the basis for the present tectonic system, which is mainly composed of synclinoria and synclines (Fig. 1).

Early in the Late Permian, controlled by a northeast tectonic framework, an inclined terrain formed from north to south and from northwest to east. Three sedimentary facies were also deposited (marine, terrestrial and interacting marine and terrestrial facies), and these controlled the coal formation in the Late Permian. From the end of the Early Permian to the Late Permian, multi-stage eruptions of Emeishan basalt magma constructed positive tectonic factor and topographic conditions. In negative tectonic activity center, the Ziyun aulacogen and the Luoping aulacogen, associated with the ancient Kangdian terrain, controlled the process of forming, developing and filling coal accumulating basins. Due to Yanshan movement, the strata preceding the Cretaceous and the coal measure strata of the coal accumulating period are strongly faulted and folded, forming the later tectonic framework. As a result, the coal bearing strata were divided and exist in many independent secondary syncline units, which generally present the tectonic characteristics of syncline controlling gas (Gui and Wang 2000; Cromie and Khin, 2003; Tao et al., 2010; Bercovici et al., 2015). 
In western Guizhou and eastern Yunnan, there are large differences in coal quality and the coal metamorphism is uneven. The maximum vitrinite reflectance is low in the central part of the region but high to the northeast and southwest. Fig. 1 shows a ring belt distribution in which the coal rank increases from the Panguan syncline to the rim. Coal metamorphism in the area is controlled by a variety of factors, including sedimentary depth, magmatic hydrothermal fluids and tectonic movement.

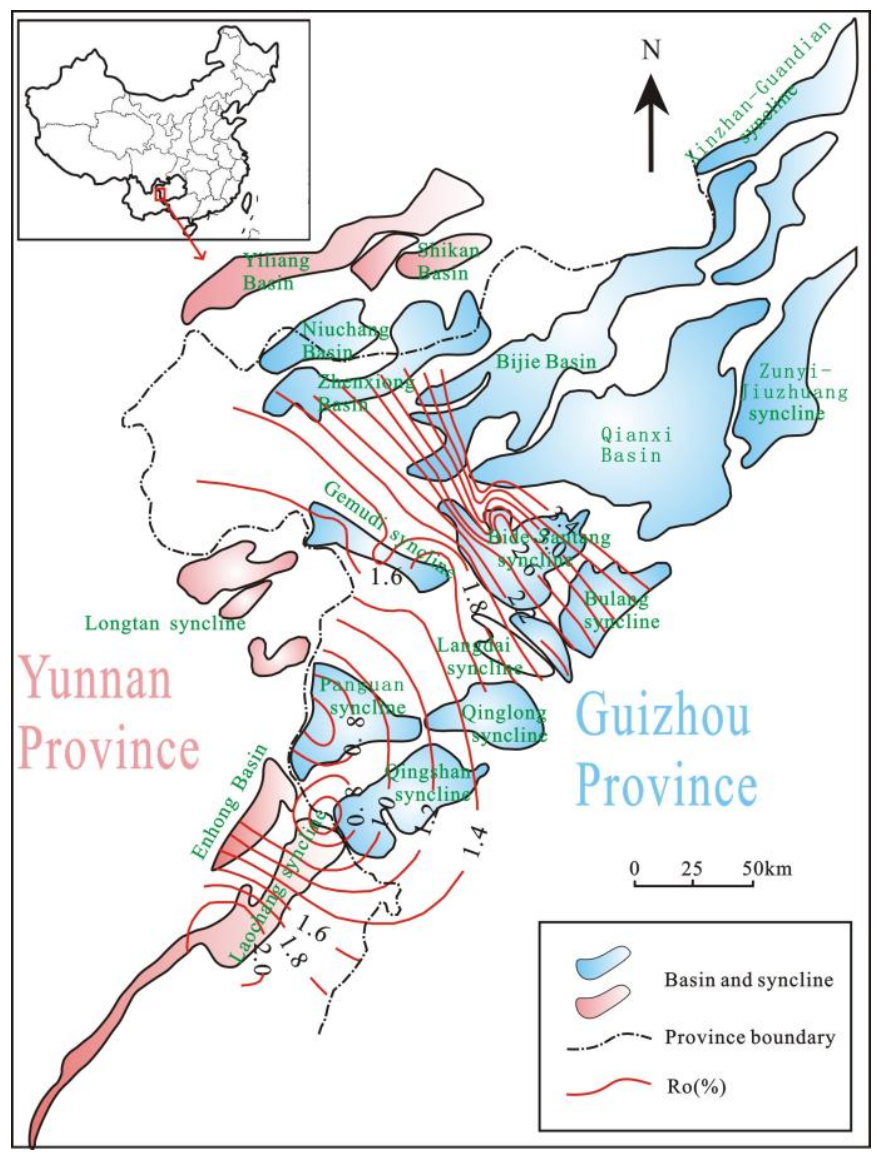

Fig. 1. Distribution of coalbed methane basins in the western Guizhou and eastern Yunnan regions.

\section{Samples and methods}

Given the high hydrothermal fluid activity in the western Guizhou and eastern Yunnan regions, it is important to characterize the thermal fluid's history through fluid inclusion analysis. To investigate hydrothermal fluid activity in the region, 40 coal and rock samples were collected from drilling (Fig.2, Table 1). We conducted a series of experiments to test the homogenization temperature, salinity and components of the fluid inclusions; we also measured the physical properties of the coal. 


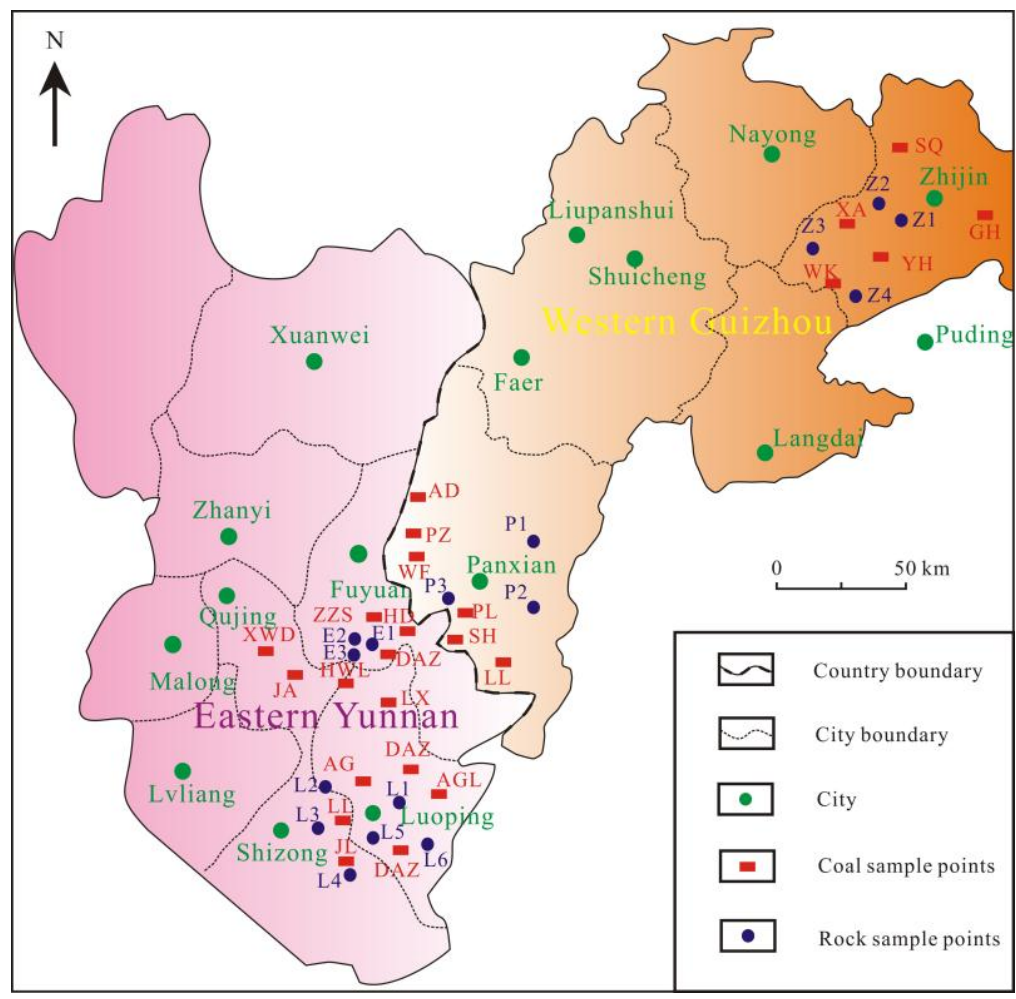

Fig.2.Sampling points in the western Guizhou and eastern Yunnan regions.

Table 1.Sample information of western Guizhou and eastern Yunnan regions

\begin{tabular}{cccc}
\hline Area & Coal samples number & Rock samples number & Depth(m) \\
\hline Panxian & GH, WK,SQ, XA, YH & P1, P2, P3 & $595-785$ \\
\hline Zhijin & AD, SH, LLP, ZW, FPL & Z1, Z2, Z3, Z4 & $647-843$ \\
\hline Laochang & DA, ZA, GL, AG, LL, JL, LX & L1, L2, L3, L4, L5, L6 & $693-876$ \\
\hline Enhong & ZZS, HD, HLW, DAZ, JA, XDW, LX & E1, E2, E3 & $622-835$ \\
\hline
\end{tabular}

In total, 16 rock samples collected by drilling (from roof and floor of coal seam) in the study area were used to measure the components of the fluid inclusions: these included inorganic components, anions and cations, and carbon and hydrogen isotopes. All the samples were first ground to $0.2-0.5 \mathrm{~mm}$ and both sides were polished under preparation temperatures below $80^{\circ} \mathrm{C}$. The measurements were made using the Laser Raman Spectroscopic Analysis Method described by Irmer, 2002 and Lascola, 2004. We used a LABHRVIS LABRAM HR800 Micro Laser Raman Spectrometer manufactured in France, which is capable of nondestructive analysis. Next, the same samples were analyzed to determine their homogenization temperature and salinity. Based on the Temperature Measurement Standard of Mineral Fluid Inclusion (EJ/T1105-1999) and established homogenization methods, the homogenization temperature of the fluid inclusions was measured on a LINKAM THMS 600 Cooling-Heating Equipment at $20^{\circ} \mathrm{C}$ and $30 \%$ humidity. Finally, the salinity (as wt \% NaCl) was calculated using the Data Conversion Table of Freezing Temperature-Salinity described by Bodnar, 1992.

The coal rank of the study area was determined from 24 coal samples collected by drilling. Based on the Chinese National Standards (GB/T6948-1998), the maximum vitrinite reflectance (Ro, max, \%) of the coal was measured using a Leitz MPV-3 photometer microscope with an MPS 
60 photo system manufactured by the Leitz Company of Germany (Fu et al., 2015).

The same 24 coal samples measured for maximum vitrinite reflectance were used to analyze the physical properties of the coal. Based on the SY/T 5162-1997 standards, they were examined using a $\sum$ IGMA/VP scanning electron microscope (SEM) to research the pore-fracture structure. Adsorption isothermal experiments were conducted with an IS100 Isothermal adsorption instrument using the equilibrium water method at $30^{\circ} \mathrm{C}$, following the Chinese National Standards (GB/T6948-1998). Based on the SY/T 6385 standard, the porosity and permeability were measured under overburden pressure; we used an AP608 permeameter and the pore structure was determined with an AUTOPORE 9500 Mercury Injection Apparatus based on the SY/T5346-2002 standard. The physical properties of the coal were ascertained from the above experiments.

\section{Results and discussion}

\subsection{The characteristics of hydrothermal fluid activity}

\subsubsection{Geological and geochemical characteristics of the hydrothermal fluids}

\section{Types of fluid inclusions}

In coal bearing strata, the host minerals for fluid inclusions are mainly calcite and quartz in the form of veins filling in rock fractures (Fig.3). These types of fluid inclusions include hydrocarbonaceous brine inclusions, gas-liquid hydrocarbon inclusions, gaseous hydrocarbon inclusions and liquid hydrocarbon inclusions (Fig.4). The tested fluid inclusions have different sizes and shapes, including spherical, elliptical, and irregular forms.

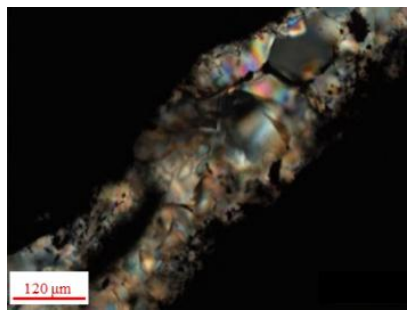

a.

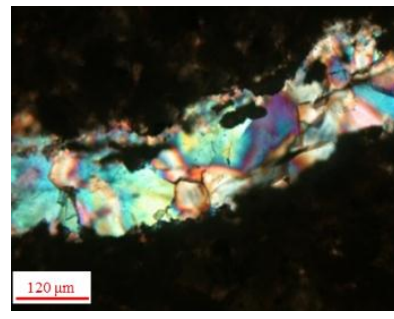

b.

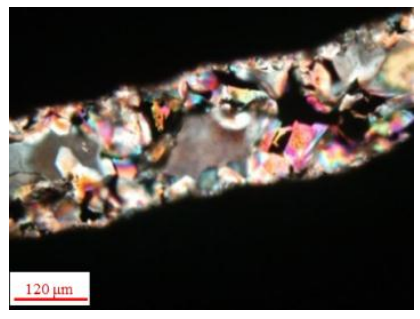

c.

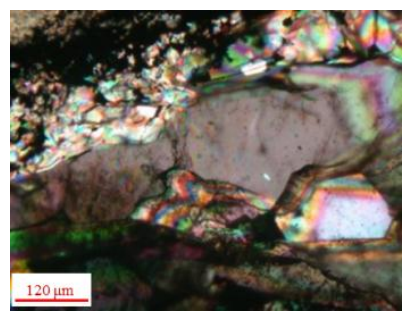

d.

Fig. 3. Mineral vein filling a rock fracture during drilling in the western Guizhou and eastern Yunnan regions.

a. Calcite vein in mudstone in the Laochang area, No: L2, Depth: $704.35 \mathrm{~m}$; b. Quartz vein in fine sandstone in the Enhong area, No: E2, Depth: 648.75 m; c. Quartz vein in sandy mudstone in the Zhijin area, No: Z1, Depth: 712.28 m; d.

Quartz vein filling in a sandy mudstone fracture in a coal roof in the Panxian area, No: P2, Depth: $671.42 \mathrm{~m}$.

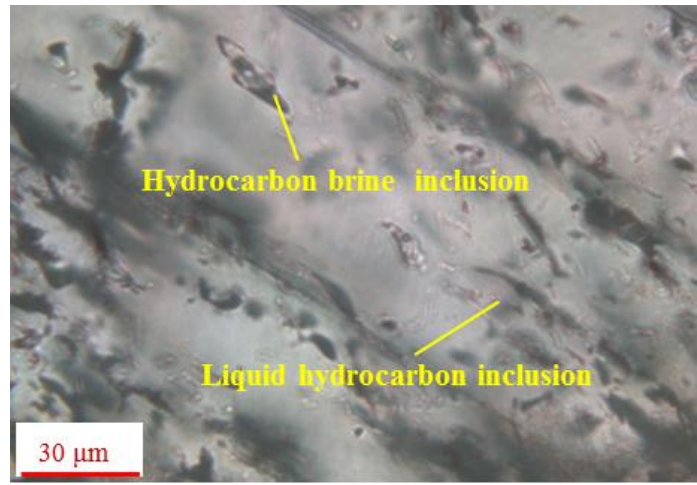

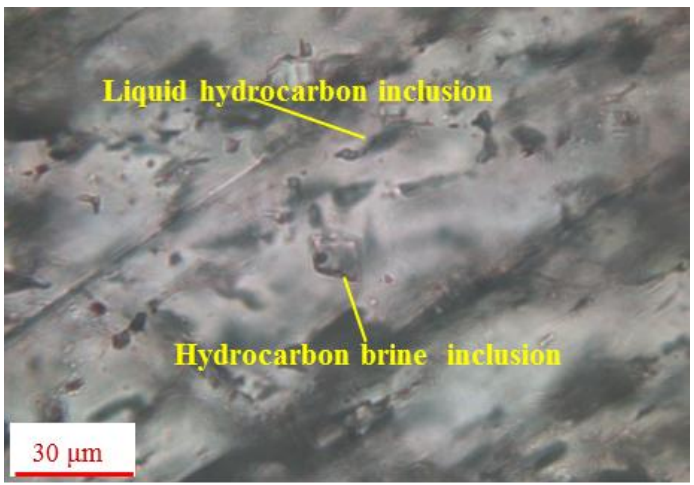




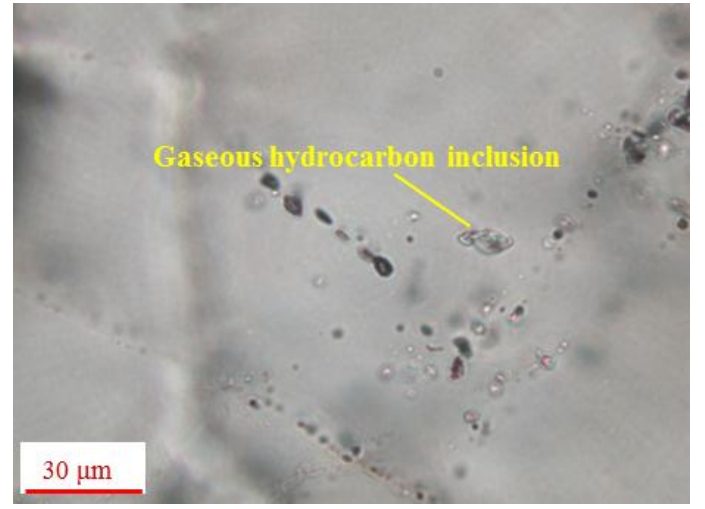

$\mathrm{c}$

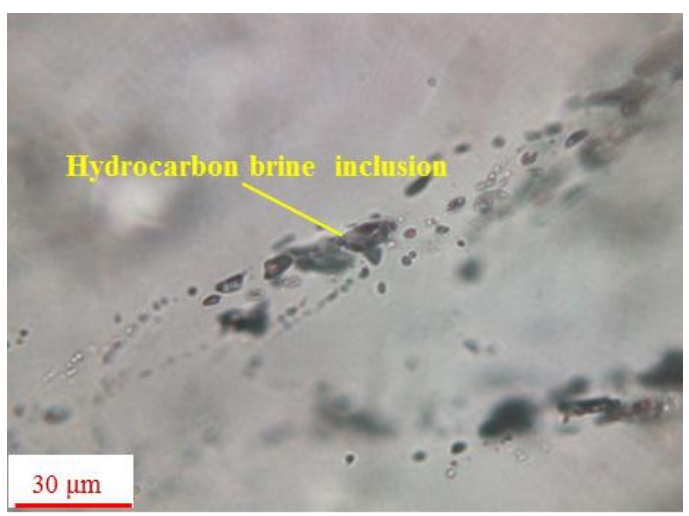

$\mathrm{d}$

Fig.4.Photographs of fluid inclusions in the western Guizhou and eastern Yunnan regions.

a, b. Yellowish-grey hydrocarbonaceous brine inclusion and dark brown liquid hydrocarbon inclusion in calcite with clumped distribution; c. Brown gaseous hydrocarbon inclusion in quartz with zonal distribution; d. Grey-brown hydrocarbonaceous brine inclusion in quartz with zonal distribution.

\section{Components of fluid inclusions}

Components analysis of the fluid inclusions shows that the organic component mainly includes methane, as well as a small amount of ethane and other hydrocarbons; this is very similar to the components revealed by CBM drilling. In the Zhijin area, the aridity coefficient of hydrocarbons is the highest, ranging from 1.01-3.82, followed by the Laochang area, ranging from 1.10-2.35. The Panxian and Enhong areas have relatively small aridity coefficients. This difference is mainly related to the degree of thermal evolution of the hydrocarbon source rock. The $\delta^{13} \mathrm{C}$ values for $\mathrm{CH}_{4}$, the $\delta \mathrm{D}$ values for $\mathrm{CH}_{4}$ and the $\delta^{13} \mathrm{C}$ values for $\mathrm{CO}_{2}$ range, respectively, from $-35.4 \%$ o to $-32.9 \%$, $-118 \%$ o to $-111 \%$ o and $-11.3 \%$ o to $-14.6 \%$ (Table 2 ). These values are also consistent with the distribution range revealed by CBM drilling. And the inorganic component largely consists of $\mathrm{H}_{2} \mathrm{O}$ and $\mathrm{CO}_{2}$ (Table 1). All these data suggest that the coalbed methane mainly originated from thermogenic hydrocarbons in the study area.

$\mathrm{Cl}^{-}, \mathrm{Na}^{+}, \mathrm{Fe}^{3+}$ are enriched in the Zhijin area and $\mathrm{SO}_{4}{ }^{2-}$ and $\mathrm{NO}_{3}{ }^{-}$are enriched in the Panxian area. There is no notable enrichment in these ions in the Laochang or Enhong areas, both of which have high amounts of $\mathrm{F}^{-}, \mathrm{SO}_{4}{ }^{2-}, \mathrm{K}^{+}$and $\mathrm{Ca}^{2+}$ (Table 3). According to the Sulin classification, the ancient strata water is classified as the $\mathrm{CaCl}_{2}$ type in the Zhijin area, but it is classified as the $\mathrm{Na}_{2} \mathrm{SO}_{4}$ and $\mathrm{MgCl}_{2}$ type in the Panxian, Laochang and Enhong areas. This suggests that the strata fluids in the Zhijin area are stranded, while fluids in the other three areas have some communication with the surface of the earth. In addition, the enrichment of $\mathrm{F}^{-}$and $\mathrm{SO}_{4}{ }^{2-}$ in the hydrothermal fluids in the Laochang and Enhong areas indicates that the alteration of coal and surrounding rocks was caused by building water mixing with underground hydrothermal fluids. The resulting fluid flowed into cracks in the rock and coal along fault fracture zones. 
Table 2.Experimental data for the components of fluid inclusions in the western Guizhou and eastern Yunnan regions

\begin{tabular}{|c|c|c|c|c|c|c|c|c|c|c|c|c|c|c|c|c|c|c|c|}
\hline \multirow{3}{*}{ Area } & \multirow{3}{*}{ Number } & \multirow{3}{*}{ Mineral } & \multicolumn{7}{|c|}{ Organic component content $(\mathrm{uL} / \mathrm{g})$} & \multirow{3}{*}{$\begin{array}{c}\text { Aridity } \\
\text { coefficient }\end{array}$} & \multicolumn{5}{|c|}{ Inorganic component content $(\mathrm{uL} / \mathrm{g})$} & \multicolumn{4}{|c|}{$\begin{array}{c}\text { Carbon and hydrogen isotopic values } \\
(\% 0)\end{array}$} \\
\hline & & & \multirow{2}{*}{$\mathrm{CH}_{4}$} & \multirow{2}{*}{$\mathrm{C}_{2} \mathrm{H}_{4}$} & \multirow{2}{*}{$\mathrm{C}_{2} \mathrm{H}_{6}$} & \multirow{2}{*}{$\mathrm{C}_{3} \mathrm{H}_{6}$} & \multirow{2}{*}{$\mathrm{C}_{3} \mathrm{H}_{8}$} & \multirow{2}{*}{$\mathrm{iC}_{4} \mathrm{H}_{10}$} & \multirow{2}{*}{$\mathrm{nC}_{4} \mathrm{H}_{10}$} & & \multirow{2}{*}{$\mathrm{H}_{2}$} & \multirow{2}{*}{$\mathrm{N}_{2}$} & \multirow{2}{*}{$\mathrm{CO}$} & \multirow{2}{*}{$\mathrm{CO}_{2}$} & \multirow{2}{*}{$\begin{array}{c}\mathrm{H}_{2} \mathrm{O} \\
\text { (Liquid) }\end{array}$} & \multicolumn{3}{|c|}{$\delta^{13} \mathrm{C}(\mathrm{PDB})$} & \multirow{2}{*}{$\frac{\delta \mathrm{D}}{\mathrm{CH}_{4}}$} \\
\hline & & & & & & & & & & & & & & & & $\mathrm{CH}_{4}$ & $\mathrm{C}_{2} \mathrm{H}_{4}$ & $\mathrm{CO}_{2}$ & \\
\hline \multirow{3}{*}{ Panxian } & P1 & \multirow{3}{*}{ Calcite } & 0.9616 & 0.2866 & 0.4049 & 0.0126 & 0.3589 & 0.001 & 0.001 & 0.90 & 23.17 & 0.5972 & 5.111 & 40.03 & 422.9 & -35.4 & - & -14.6 & - \\
\hline & $\mathrm{P} 2$ & & 1.1610 & 0.2649 & 0.4867 & 0.0068 & 0.3075 & 0.0158 & 0 & 1.07 & 21.53 & 0.7691 & 3.099 & 40.02 & 335.2 & - & - & -12.8 & - \\
\hline & P3 & & 0.7471 & 0.0592 & 0.3044 & 0.0019 & 0.1543 & 0 & 0.0141 & 1.40 & 11.78 & 0.2773 & 0.787 & 15.11 & 195.2 & - & - & -14 & - \\
\hline \multirow{4}{*}{ Zhijin } & $\mathrm{Z} 1$ & \multirow{4}{*}{ Calcite } & 1.0710 & 0.2627 & 0.4066 & 0.0143 & 0.3472 & 0 & 0 & 1.04 & 24.04 & 0.7657 & 6.985 & 63.63 & 300.5 & -32.9 & - & - & -114 \\
\hline & $\mathrm{Z} 2$ & & 2.4910 & 0.918 & 1.114 & 0.0086 & 0.4197 & 0.001 & 0 & 1.01 & 25.49 & 3.613 & 18.78 & 108.2 & 354.6 & - & - & - & - \\
\hline & $\mathrm{Z} 3$ & & 1.1810 & 0.1067 & 0.334 & 0.0026 & 0.1496 & 0 & 0 & 1.99 & 20.13 & 0.7901 & 3.517 & 21.37 & 188.8 & -35.1 & -42.1 & -11.3 & -118 \\
\hline & $\mathrm{Z} 4$ & & 1.0530 & 0.0304 & 0.1862 & 0 & 0.0588 & 0 & 0 & 3.82 & 17.19 & 0.881 & 2.486 & 32.33 & 237.4 & -33.9 & - & -11.8 & -111 \\
\hline \multirow{6}{*}{ Laochang } & L1 & \multirow{4}{*}{ Calcite } & 1.0143 & 0.1872 & 0.1769 & 0.0216 & 0.2576 & 0.002 & 0 & 1.10 & 12.96 & 0.136 & 1.643 & 47.09 & 233.1 & -33.5 & - & -11.5 & - \\
\hline & L2 & & 1.7012 & 0.2019 & 0.3191 & 0.0231 & 0.1773 & 0 & 0 & 1.32 & 18.67 & 0.0614 & 4.357 & 59.21 & 122.4 & - & -40.0 & -12.3 & - \\
\hline & L3 & & 0.9706 & 0.2038 & 0.2873 & 0.0012 & 0.0982 & 0.0001 & 0.0001 & 1.89 & 16.19 & 0.0958 & 10.34 & 77.58 & 231.2 & -34.1 & - & -11.8 & - \\
\hline & L4 & & 1.0523 & 0.1692 & 0.4183 & 0.0046 & 0.2103 & 0.0015 & 0 & 2.35 & 14.87 & 0.116 & 2.356 & 45.39 & 173.5 & -33.1 & - & -13.4 & - \\
\hline & L5 & \multirow{2}{*}{ Quartz } & 1.1226 & 0.1174 & 0.3238 & 0.0023 & 0.1736 & 0 & 0 & 1.19 & 15.54 & 0.1317 & 4.586 & 48.46 & 372.1 & - & - & - & - \\
\hline & L6 & & 1.8924 & 0.2132 & 0.1729 & 0.0061 & 0.0213 & 0.0121 & 0 & 2.13 & 23.63 & 0.1062 & 0.241 & 17.25 & 157.9 & -34.7 & -41.3 & - & - \\
\hline \multirow{3}{*}{ Enhong } & E1 & Calcite & 0.8976 & 0.2938 & 0.2128 & 0.0038 & 0.2128 & 0 & 0.001 & 1.03 & 19.20 & 0.2313 & 1.102 & 34.32 & 321.4 & -35.1 & - & -11.9 & -113 \\
\hline & E2 & \multirow{2}{*}{ Quartz } & 0.9148 & 0.2101 & 0.3172 & 0.0132 & 0.3329 & 0.0016 & 0 & 1.06 & 17.35 & 0.0537 & 2.346 & 23.53 & 402.5 & -34.6 & - & -12.6 & - \\
\hline & E3 & & 1.0241 & 0.1982 & 0.4037 & 0.0073 & 0.1826 & 0.0013 & 0.001 & 1.38 & 10.26 & 0.2194 & 5.372 & 76.35 & 185.3 & - & -40.2 & - & -116 \\
\hline
\end{tabular}


Table 3.Anion and cation content of fluid inclusions in the western Guizhou and eastern Yunnan regions (ug/g)

\begin{tabular}{|c|c|c|c|c|c|c|c|c|c|c|c|c|}
\hline Area & Number & $\mathrm{F}^{-}$ & $\mathrm{Cl}^{-}$ & $\mathrm{NO}_{3}^{-}$ & $\mathrm{SO}_{4}{ }^{2-}$ & $\mathrm{K}^{+}$ & $\mathrm{Ca}^{2+}$ & $\mathrm{Al}^{3+}$ & $\mathrm{Fe}^{3+}$ & $\mathrm{Mg}^{2+}$ & $\mathrm{Na}^{+}$ & $\begin{array}{c}\text { Surin } \\
\text { classification }\end{array}$ \\
\hline \multirow{3}{*}{ Panxian } & $\mathrm{P} 1$ & 0.5762 & 0.6195 & 0.5119 & 2.7000 & 0.1874 & 42.9300 & 0.1961 & 0.0642 & 0.5744 & 0.5952 & $\mathrm{MgCl}_{2}$ \\
\hline & $\mathrm{P} 2$ & 0.7186 & 1.1980 & 0.7775 & 7.3890 & 0.4385 & 11.6700 & 0.1685 & 0 & 3.8310 & 1.6810 & $\mathrm{Na}_{2} \mathrm{SO}_{4}$ \\
\hline & P3 & 0.2319 & 0.3538 & 0.2506 & 2.7830 & 0.1422 & 22.1300 & 0.1862 & 0.0576 & 0.2404 & 0.3149 & $\mathrm{MgCl}_{2}$ \\
\hline \multirow{4}{*}{ Zhijin } & $\mathrm{Z} 1$ & 0.1504 & 1.6050 & 0.1657 & 1.5100 & 0.1949 & 17.3200 & 0.0614 & 0.1488 & 0.3821 & 0.7917 & $\mathrm{CaCl}_{2}$ \\
\hline & $\mathrm{Z} 2$ & 0.1687 & 2.2260 & 0.0920 & 1.5120 & 0.1564 & 20.8400 & 0.0429 & 0.1073 & 0.5336 & 1.0290 & $\mathrm{CaCl}_{2}$ \\
\hline & $\mathrm{Z3}$ & 0.5637 & 3.7420 & 0.1567 & 1.3460 & 0.1260 & 24.6700 & 0.0645 & 0.1889 & 0.2473 & 1.3390 & $\mathrm{CaCl}_{2}$ \\
\hline & $\mathrm{Z} 4$ & 0.2019 & 3.4100 & 0.3622 & 3.4440 & 0.1187 & 17.5200 & 0.0955 & 0.0909 & 1.0430 & 1.7550 & $\mathrm{CaCl}_{2}$ \\
\hline \multirow{6}{*}{ Laochang } & L1 & 3.1660 & 0.9479 & 0.0657 & 26.3300 & 0.8977 & 78.3900 & 0.0334 & 0.0632 & 1.2150 & 0.7393 & $\mathrm{MgCl}_{2}$ \\
\hline & L2 & 4.0505 & 0.4504 & 0.1054 & 13.9100 & 0.9790 & 59.6700 & 0.0283 & 0.0920 & 1.9580 & 1.3570 & $\mathrm{Na}_{2} \mathrm{SO}_{4}$ \\
\hline & L3 & 1.9240 & 0.7884 & 0.0727 & 46.6500 & 0.7831 & 79.1700 & 0.0218 & 0.1517 & 2.4020 & 0.8353 & $\mathrm{Na}_{2} \mathrm{SO}_{4}$ \\
\hline & $\mathrm{L} 4$ & 2.8430 & 0.7960 & 0.0953 & 2.0340 & 0.5378 & 79.8700 & 0.1231 & 0.0920 & 0.3765 & 1.5870 & $\mathrm{Na}_{2} \mathrm{SO}_{4}$ \\
\hline & L5 & 1.2480 & 0.5338 & 0.1651 & 4.5960 & 0.3700 & 16.8600 & 0.0920 & 0.0164 & 0.1321 & 0.4490 & $\mathrm{MgCl}_{2}$ \\
\hline & L6 & 5.0050 & 1.7870 & 0.1715 & 15.0500 & 2.8940 & 64.3300 & 0.0920 & 0.0526 & 1.0530 & 2.2240 & $\mathrm{Na}_{2} \mathrm{SO}_{4}$ \\
\hline \multirow{3}{*}{ Enhong } & E1 & 2.8720 & 0.8720 & 0.3345 & 8.6890 & 1.0264 & 64.8000 & 0.0684 & 0.0587 & 0.8226 & 0.6033 & $\mathrm{MgCl}_{2}$ \\
\hline & E2 & 1.3940 & 0.9750 & 0.2712 & 7.1830 & 0.4739 & 32.3400 & 0.0483 & 0.0392 & 1.1030 & 0.8000 & $\mathrm{MgCl}_{2}$ \\
\hline & E3 & 0.9280 & 0.7430 & 0.2338 & 2.2150 & 0.7219 & 46.4300 & 0.0192 & 0.0617 & 0.5280 & 1.1260 & $\mathrm{Na}_{2} \mathrm{SO} 4$ \\
\hline
\end{tabular}

\subsubsection{Origin and formation stage of the hydrothermal fluid}

Hydrothermal fluid in coal basins can be divided into two types based on the fluid source and thermal energy: these are deeply circulating hot water and magmatic differentiation hydrothermal fluid. The former consists of surface water and meteoric precipitation, which infiltrate deep underground along rock pores and fractures, where they absorb geothermal energy and form high temperature water. Next, the hot water upwells along a deep fault belt and extends and overflows at the surface through shallow faults and permeable layers. Finally, it forms a continuously cycling system. The latter is induced by the differentiation of solid and liquid phases during cooling of magmatic intrusions. As the magma cools, some of its constituent minerals crystallize into solid igneous rock, which stays deep underground. However, the gas and liquid phase materials migrate upward along the fracture passage to form magmatic hydrothermal fluid. After entering a coal field, both the magmatic hydrothermal fluid and hot water can cause an abnormally high thermal field, which can lead to coal metamorphism. There are few mineral types and a low solute concentration in the hot water; these are generally calcium carbonate or colloidal $\mathrm{SiO}_{2}$ solution (concentrations range from 1\%-2\%), which form calcite or quartz veins and induce carbonatization and silicified alterations. The solution is often alkalescent, with dissolved substances derived from the surrounding rock based on the migration path of the hot water. Various dissolved materials can occur in the magmatic hydrothermal fluids, with solubility ranging from $8 \%-10 \%$, The solute often contains volatile elements because of magmatic differentiation (e.g., $\mathrm{F}, \mathrm{Cl}$ and $\mathrm{S}$ ), water soluble salts (e.g., $\mathrm{SO}_{4}{ }^{2-}, \mathrm{CO}_{3}{ }^{2-}$, and $\mathrm{Si}_{3} \mathrm{O}_{8}{ }^{4-}$ ) and associated metal cations. The solution is often acidic, which can form pegmatite quartz and metalliferous veins, and exchange elements with the surrounding rock to give rise to more complex rock alteration (Barker et al., 1998; Copard et al., 2000; Dai et al., 2013; Grafka et al., 
2014).

The formation sequence of the host minerals suggests that there were two main stages of thermal fluid activity in the study area. In the earlier stage, calcium fluid acted as the carrier, while in the later stage, it was replaced by siliceous fluid with a small amount of calcium fluid. In the Zhijin area, the homogenization temperature of inclusions in the calcite and quartz has two peaks, representing the two stages of fluid activity. Temperatures for the two stages ranged from $100-130^{\circ} \mathrm{C}$ and $180-200^{\circ} \mathrm{C}$, respectively, and the highest fluid temperature reached $248^{\circ} \mathrm{C}$ (Fig. 5a). In the Panxian area, based on carrier type and temperature range, the fluid active stages can also be divided into two stages. For the first stage of fluid activity with calcium fluid as the carrier, the temperature during the initial period ranged from $60-80^{\circ} \mathrm{C}$ (Fig. $5 \mathrm{~b}$ ); for the second stage with siliceous fluid as the carrier, the temperature ranged from $130-150^{\circ} \mathrm{C}$. The temperature results for the Laochang and Enhong areas also show significant differences between the fluid temperature ranges of the two stages (Figs. 5c, d). Overall, the temperature of the siliceous fluid activity was higher than the temperature of calcium fluid activity in the study area.
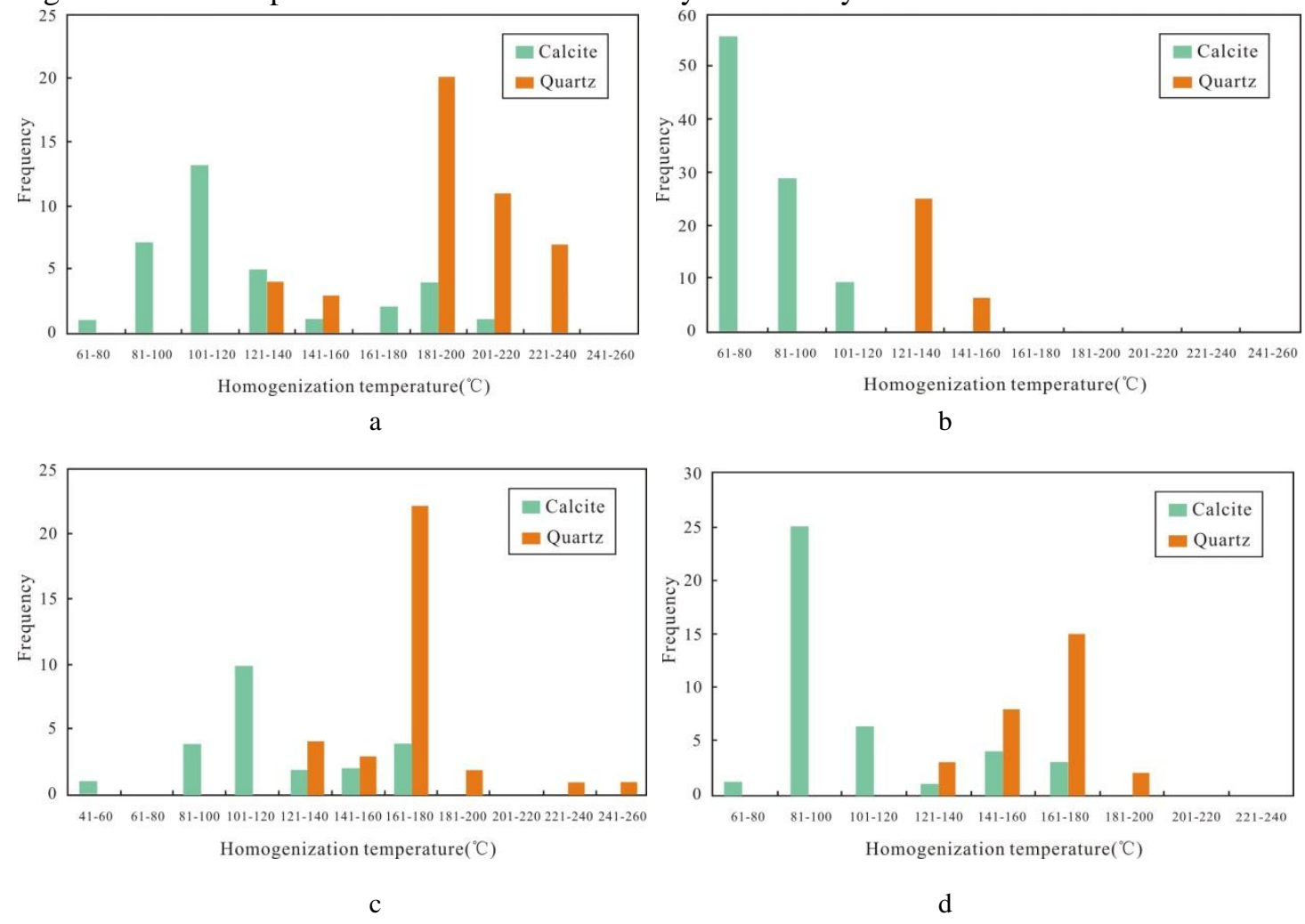

c

d

Fig.5. Histogram of the homogenization temperature of fluid inclusions.

a. Zhijin area; b. Panxian area; c. Laochang area; d. Enhong area 


\subsection{Geological mechanisms of the effects of hydrothermal fluid}

\subsubsection{Stimulation for hydrocarbon generation}

The Basin-Mod Basin simulation software was used to model the region's sedimentary burial history and thermal evolution. We calculated organic maturity and hydrocarbon generation quantities using the Lawrence Livermore National Laboratories (LLNL) dynamics model (Sweeney and Burnham, 1990; Yuan, et al, 2010), with the measured Ro restricting processes in the simulation (Fig. 6).

The simulation results show that the Upper Permian coal seam in the Zhijin area entered the early mature stage during the late period of Triassic; at this time, the ground temperature was $90^{\circ} \mathrm{C}$, corresponding to the long-flame coal stage (Table 4) when the Ro is $0.5-0.7 \%$. The coal seam entered the middle mature stage in the early period of Jurassic; the ground temperature was $115^{\circ} \mathrm{C}$, which corresponds to the gas coal stage when the Ro is $0.7-1.0 \%$. It entered the late mature stage in the late period of the Early Jurassic; the ground temperature was $140^{\circ} \mathrm{C}$, which corresponds to the fat coal and coking coal stage, with an Ro max from 1-1.3\%. Finally, the coal seam entered the highly mature stage in the late period of Late Jurassic, when the ground temperature was $90^{\circ} \mathrm{C}$ and the Ro varied from 1.3-2.6\%, corresponding to the long-flame coal stage.

Because of its shallow burial depth and small geothermal gradient, the coalification degree in the Panxian area is lower than in the Zhijin area. The coal in the Upper Permian did not reach early maturity until the late period of Triassic, when the ground temperature was $85^{\circ} \mathrm{C}$; this corresponds to the long-flame coal stage, when the Ro is $0.5-0.7 \%$. It entered the middle mature stage in the early period of Late Jurassic, when the ground temperature was $110^{\circ} \mathrm{C}$, which corresponds to gas coal and an Ro of $0.7-1.0 \%$. After this time, coalification stopped because of strata uplift.

In the Enhong and Laochang areas, the coal seam entered the early mature stage in the late period of Late Permian, when the ground temperature was $85^{\circ} \mathrm{C}$; this corresponds to the long-flame coal to gas coal stage and an Ro of $0.5-0.7 \%$. It entered the middle mature stage in the late period of Middle Jurassic; the ground temperature was $110^{\circ} \mathrm{C}$, which corresponds to the gas coal to fat coal stage, when the Ro is $0.7-1 \%$. Coalification also stopped in the Enhong area because of strata uplift. The coal in the Laochang area continued to enter the late mature stage during the late period of Jurassic, when the ground temperature was $144^{\circ} \mathrm{C}$; this corresponds to gas coal and an Ro of $1.2-1.7 \%$.

Table 4. Coal type and formation temperature (According to Yang, 1982)

\begin{tabular}{cc}
\hline Coal type & Formation temperature $\left({ }^{\circ} \mathrm{C}\right)$ \\
\hline lignite $\rightarrow$ long flame coal & $40-50$ \\
\hline long flame coal $\rightarrow$ gas coal & $70-90$ \\
\hline gas coal $\rightarrow$ fat coal & $100-120$ \\
\hline fat coal $\rightarrow$ coking coal & $120-140$ \\
\hline coking coal $\rightarrow$ meagre coal & $150-180$ \\
\hline meagre coal $\rightarrow$ semianthracite & $170-200$ \\
\hline semianthracite $\rightarrow$ anthracite & $190-220$ \\
\hline
\end{tabular}




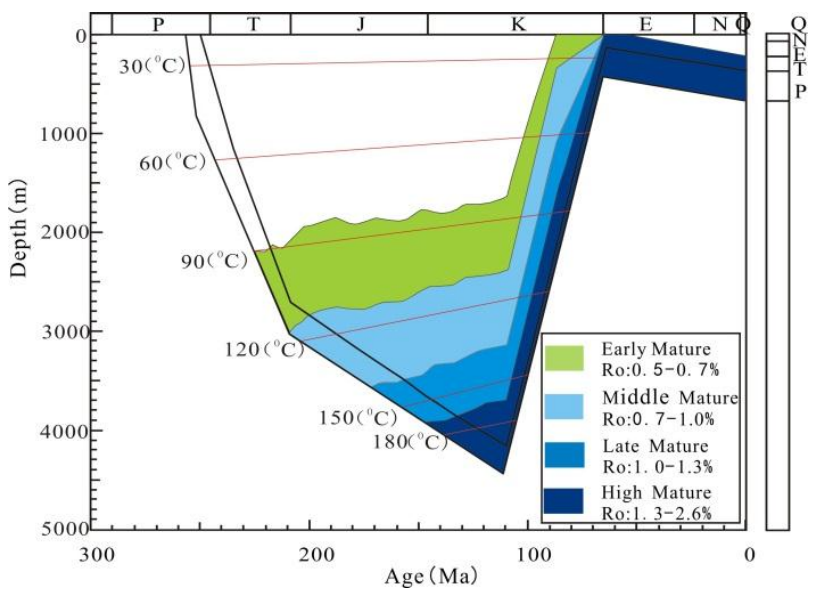

a

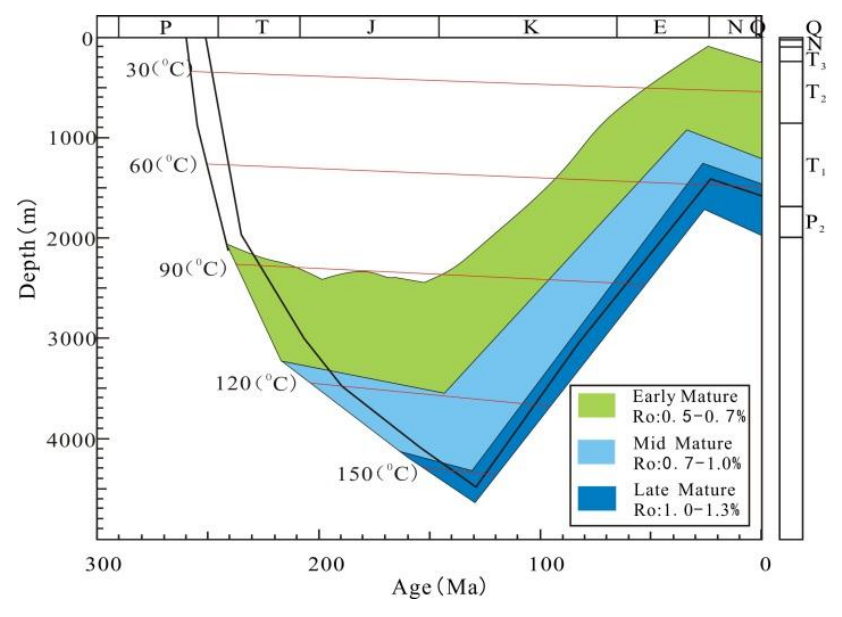

c

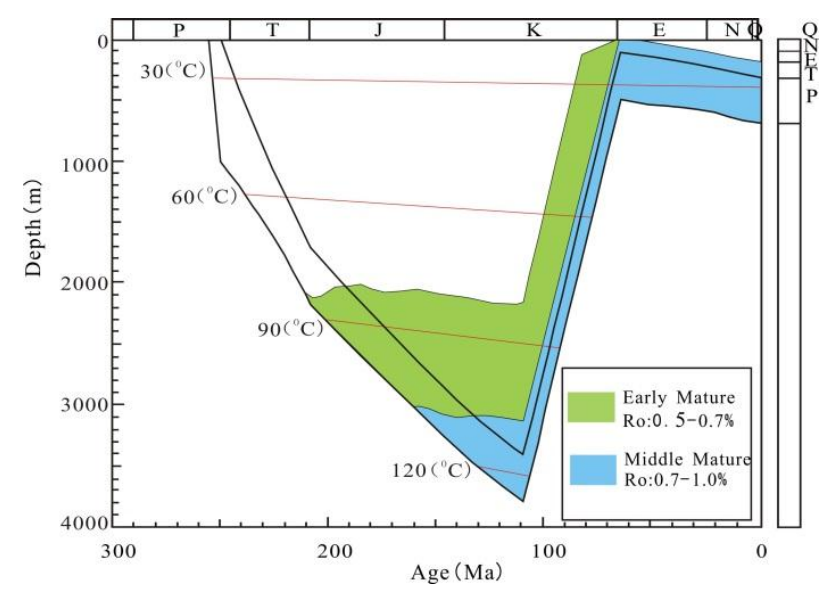

$\mathrm{b}$

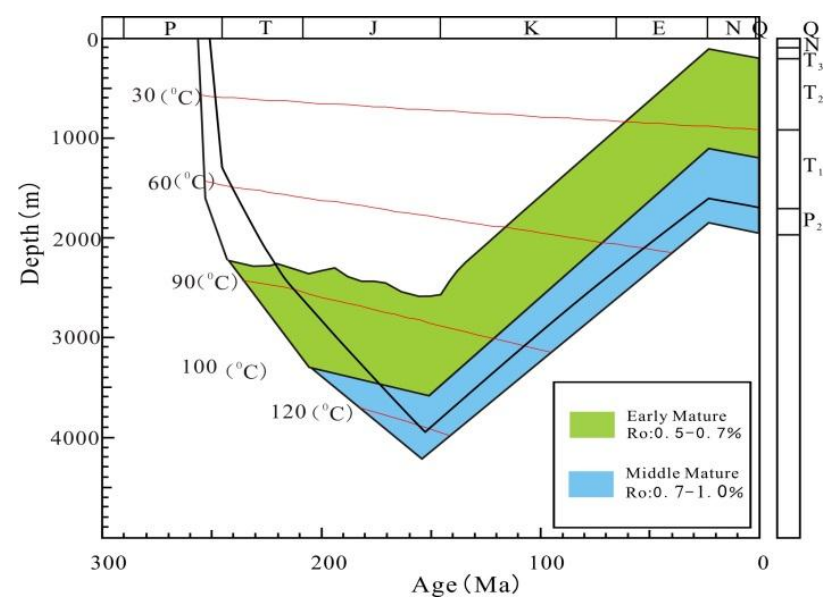

d

Fig. 6. Burial history and thermal evolution of coal seams in the study area.

a: Zhijin area; b: Panxian area; c: Laochang area; d: Enhong area

Simulations of the thermal evolution history show that the coal evolution degree reached the meager coal stage in the Zhijin area, where the Ro does not exceed 2.6\%. However, the measured Ro of the coal samples was as high as $1.64-3.35 \%$, which includes the anthracite stage. The measured homogenization temperatures of drilled fluid inclusions ranged from $115-244^{\circ} \mathrm{C}$ (Table 5), which can be divided into two stages. The temperature of the first stage is $115-192^{\circ} \mathrm{C}$; this was caused by plutonic metamorphism of the coal seam and consistent with the simulation results for the sedimentary burial history; the thermal fluid is mainly original bound water. The temperature of the second stage ranges from $206-244^{\circ} \mathrm{C}$. These high temperatures reflect the intrusion of mantle-derived magmatic hydrothermal fluid. These fluids had an abnormal thermal effect on the Late Permian strata.

The measured Ro in the Panxian area ranges from 0.72-1.27\%, and its degree of evolution reaches the fat coal stage. This is higher than the degree achieved during thermal evolution simulation, which only indicated the gas coal stage. Based on the temperature measurements of the inclusions, we conclude that the evolution of coal in this area is the result of plutonic metamorphism superimposed on abnormal thermal metamorphism. The homogenization temperatures can be divided into two stages: the first ranges from $65^{\circ} \mathrm{C}$ to $119^{\circ} \mathrm{C}$, corresponding to the palaeogeothermal gradient during the Late Permian. The second ranges from $135-150^{\circ} \mathrm{C}$ and resulted from later hydrothermal fluid events. 
The measured Ro in the Enhong area ranges from $0.88 \%$ to $1.39 \%$, and the metamorphism degree reached the coking coal stage. In simulation, the Ro only reached $1.0 \%$, corresponding to the fat coal stage. The homogenization temperature ranges from $81-192^{\circ} \mathrm{C}$, which can also be divided into two stages, one from $81-110^{\circ} \mathrm{C}$ and one at higher temperatures of $135-150^{\circ} \mathrm{C}$. The latter probably occurred because ancient strata fluids were captured during the Late Permian.

The measured Ro in the Laochang area ranges from 1.37-2.32\%, corresponding to the coking coal to meager coal stage, but the Ro in simulations only reached $1.7 \%$, corresponding to the fat coal stage. The homogenization temperature of the inclusions ranges from $56^{\circ} \mathrm{C}$ to $264^{\circ} \mathrm{C}$ but largely measures $80-170^{\circ} \mathrm{C}$. These temperatures can also be divided into two periods, one from $56-140^{\circ} \mathrm{C}$, which reflects plutonic metamorphism of the coal seam, with the thermal fluid mainly derived from original bound water. The temperature of second period ranges from $180^{\circ} \mathrm{C}$ to $220^{\circ} \mathrm{C}$; these higher temperatures were induced by magmatic hydrothermal fluids in the coal measure strata.

Table 5.Homogenization temperature of inclusion and comparison of simulated and measured Ro

\begin{tabular}{cccccc}
\hline \multirow{2}{*}{ Area } & \multicolumn{2}{c}{ Ro $(\%)$} & \multicolumn{2}{c}{ Homogenization temperature of inclusion $\left({ }^{\circ} \mathrm{C}\right)$} \\
\cline { 2 - 6 } & Simulation & Measurement & Range & First period & Second period \\
\hline Zhijin & $1.3-2.6$ & $1.64-3.35$ & $115-244$ & $115-192$ & $206-244$ \\
\hline Panxian & $0.7-1.0$ & $0.72-1.27$ & $65-150$ & $65-119$ & $135-150$ \\
\hline Laochang & $1.2-1.7$ & $1.37-2.32$ & $56-264$ & $56-140$ & $180-220$ \\
\hline Enhong & $0.7-1.0$ & $0.88-1.39$ & $81-192$ & $81-110$ & $145-192$ \\
\hline
\end{tabular}

The thermal evolution of coal in the western Guizhou and eastern Yunnan regions occurred in two periods, the pre-Yanshan period and the Yanshan period. In the pre-Yanshan period, the thermal evolution was largely controlled by plutonic metamorphism, while regional magmatic thermal metamorphism occurred during the Yanshan period. Differences in temperature of the thermal fluid activities during the pre-Yanshan period were mainly caused by the sedimentary burial depth; the maximum ancient buried depth of the coal-bearing strata in the Zhijin, Laochang, Panxian, and Enhong areas reached 4500 m, 4300 m, 3500 m and 3800 m, respectively. Because of heating differences during the second period, fluid temperatures in the Zhijin and Laochang areas were significantly higher than in the Panxian and Enhong areas. The influence of the crustal structure meant that the buried depth of the Mohorovicic discontinuity in the Zhijin and Laochang areas was shallower than in the Panxian and Enhong areas (Boyd and Smithson, 1993; Gui and Wang, 2000; Mutter and Carton, 2013; Xu et al., 2014). However, there were also differences in magmatic activity between these four areas during the Yanshan period. In the Zhijin area in particular, the effect of metamorphic heating on the coal measure strata was more significant. Under the influence of the abnormal geothermal gradient during the Yanshan period, the coal rank and coal hydrocarbon generation rate increased in parts of the region, especially in areas with large faults. There are large amounts of metamorphic pores in these areas caused by the invasion of mantle-derived magma and strong thermal fluid flow; these lead to a rapid increase in the metamorphic degree of coal and strong coalbed methane generation. Thus, regional hydrothermal fluid activity facilitated the evolution of coal to anthracite in most of the Zhijin area, and also increased the coal rank of the Laochang, Panxian, and Enhong areas.

\subsubsection{Transformation for physical properties}


The physical properties of coal reservoirs generally change with the coal rank. For low-rank coal, coal reservoirs have relatively high porosity and permeability but a poor adsorption capacity. With increasing depth in the coal seam, the coal metamorphism degree rises, which decreases the porosity and permeability and improves the adsorption ability according with the general evolution of physical properties (Gamson et al,. 1998; Karacan and Okandan, 2001; Cooper et al,. 2007; Solano et al,. 2007; Ding et al,. 2011).

Medium rank coal reservoirs in the Zhijin and Laochang areas follow this rule; they have low porosity and poor permeability (Table 6) and their Ro values range from $1.64 \%$ to $3.31 \%$ and $1.37 \%$ to $2.32 \%$, respectively. In contrast, the low and medium rank coal reservoirs in the Panxian and Enhong areas have high porosity and favorable permeability, with Ro values ranging from $0.71 \%$ to $1.27 \%$ and $0.88 \%$ to $1.39 \%$, respectively. The CBM adsorption capacity of coal samples in Zhijin and Laochang area is relatively high and there are abundant micropores and transition pores. The average Langmuir volume of the raw coal in the Zhijin and Laochang areas is $32.72 \mathrm{~m}^{3} / \mathrm{t}$ and $25.23 \mathrm{~m}^{3} / \mathrm{t}$. This is much higher than in the Panxian and Enhong areas, where it is lower than $15 \mathrm{~m}^{3} / \mathrm{t}$.

Table 6.Physical properties of coal reservoirs in the study area

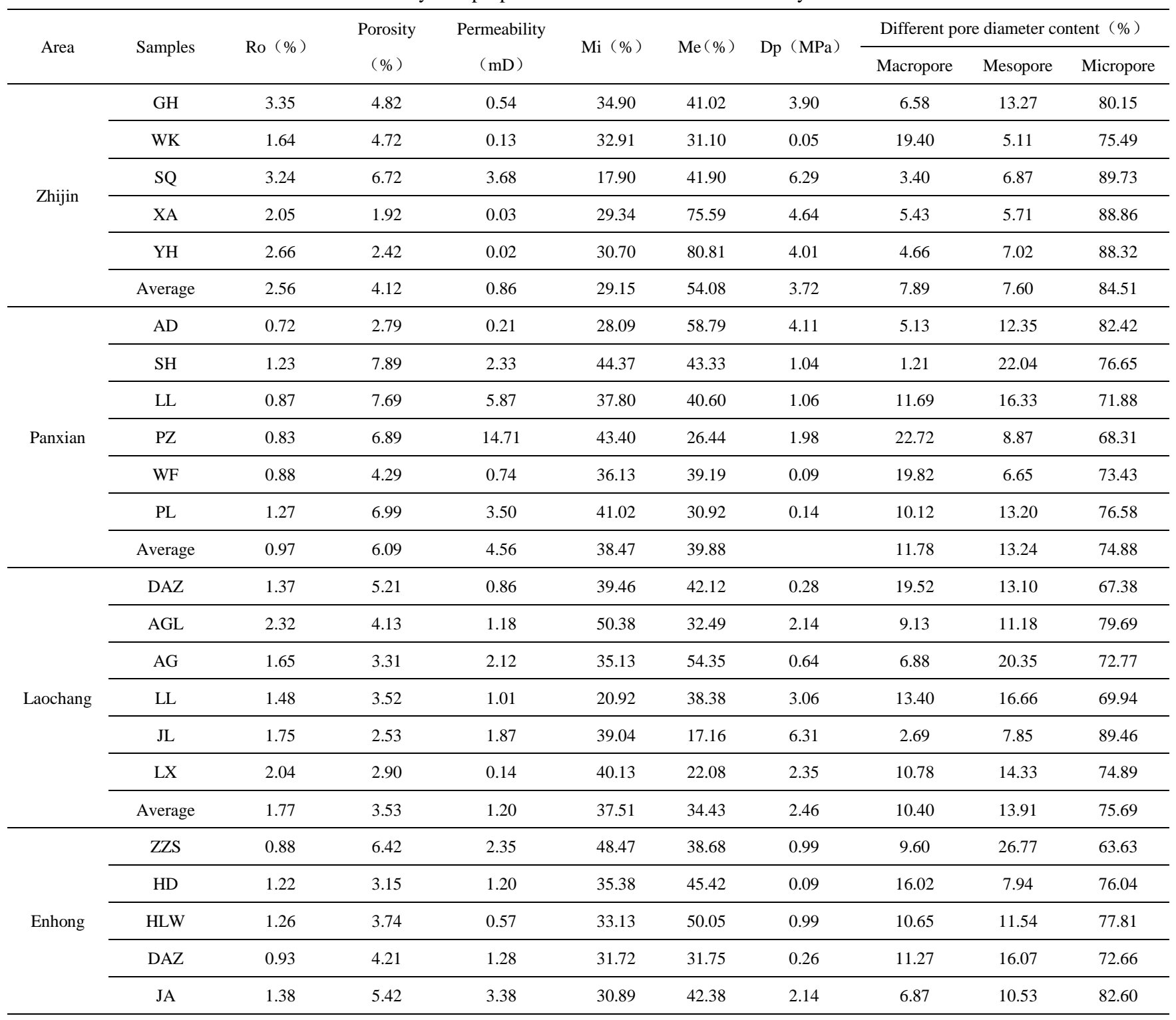




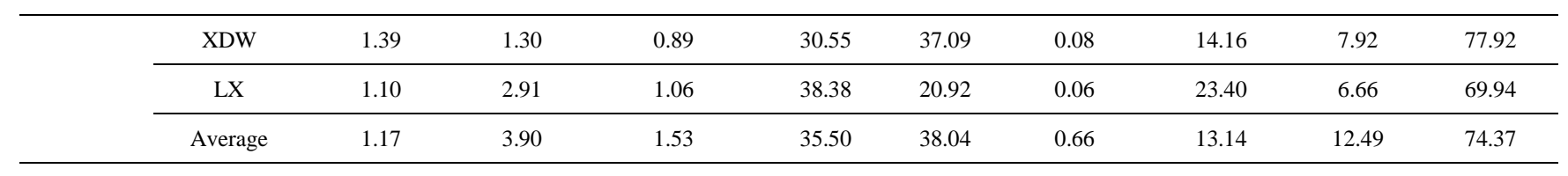

Mi: Mercury injection saturation; Me: Mercury ejection efficiency; Dp: Displacement pressure

However, the effect of thermal fluid events is not confined to general changes in the physical properties of the coal reservoir as restricted by coal rank, it also plays a dominated role in coal physical properties. First, high temperatures induce high intensity generation and migration of coalbed methane, along with producing dense swarms of tubular pores (Fig. 7), which increases the porosity. Samples SQ and GH in the Zhijin area have higher coal ranks, with Ro values of $3.24 \%$ and $3.35 \%$, but they also have much higher porosity than the other samples. Similarly, in the Panxian, Laochang and Enhong areas, samples PL, SH, AGL and JA have relatively high coal ranks and higher porosity; this abnormal increase in porosity is associated with higher micropore content.

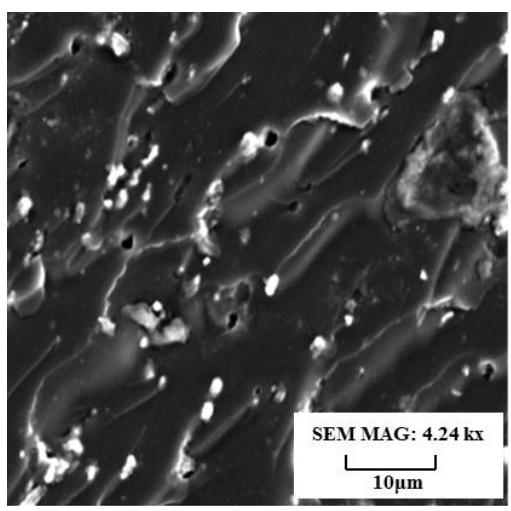

a

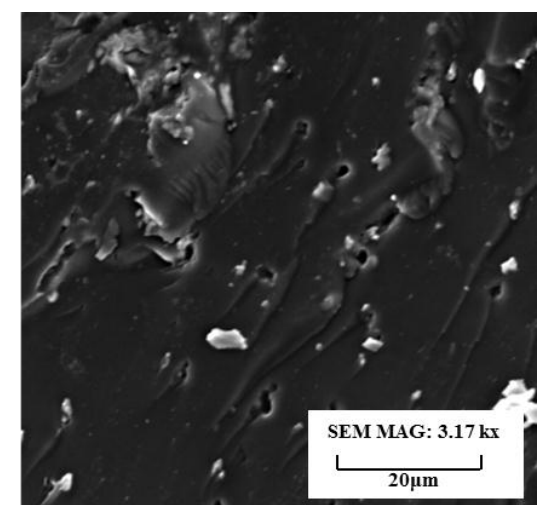

b

Fig. 7. Scanning electron microscopy image of coal pore structures in the study area.

a. Sample SQ in Zhijin area; b. Sample AGL in Laochang area

In addition, the invasion, derivation, extrusion and wedging effects of hydrothermal fluid can break the coal body, increasing its permeability. These effects are coincident with tectonic stress. The high metamorphic degree of the coal and the intense tectonic action that later occurred mean that the coal reservoir in the Zhijin area has a large number of fractures. These are especially well-developed in areas where there are faults. Generally, the fractures are both long and wide, and only some parts of the fractures are filled by minerals (Fig. 8). The growth of these fractures caused abnormally high permeability in certain samples. One example is sample SQ from the Zhijin area; despite its high coal rank, its permeability still reaches $3.68 \mathrm{mD}$. The sample was collected the north of the Zhijin area, close to the Nayong-Wengan fault, where the effects of both structure and fluid are relatively strong. In sum, fracture development improved the permeability of coal in the area. 


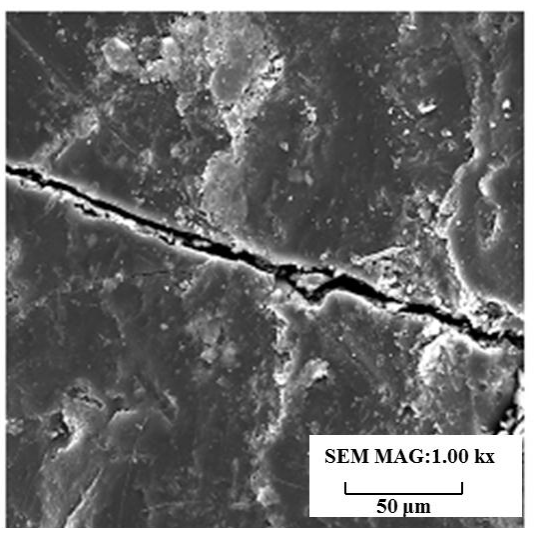

a

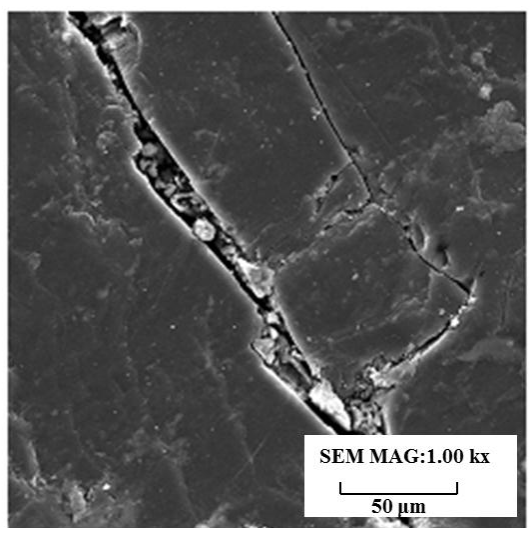

b

Fig.8. Scanning electron microscopy images of the fracture system in coal reservoirs in the Zhijin and Panxian areas.

a. Sample SQ is not filled; b. Sample GH, parts are filled by minerals

\subsubsection{Fluid supercharging effect}

Analysis of coal reservoir pressure shows that the pressure coefficient ranges from 0.89 to 2.54 in western Guizhou Province (Table 7). Pressure coefficients of 0.9 and 1.1 define the boundaries of low pressure, normal pressure and high pressure, respectively (Law 1985; Hunt 1990; Michael and Bachu, 2001; Su et al. 2003; Xie et al. 2003; Xu et al. 2011). Thus, the coal reservoirs are mainly normal and high pressure system reservoirs. There are large differences in pressure coefficient between different tectonic units of the same coal seam, as well as between the same tectonic unit in different coal seams, demonstrating strong heterogeneity.

Table 7.Pressure coefficients for the major tectonic units of the coal reservoir in western Guizhou Province

\begin{tabular}{|c|c|c|c|}
\hline Tectonic units & Well number & Coal seam & Pressure coefficient \\
\hline \multirow{7}{*}{ Panguan syncline } & \multirow{2}{*}{ QH02 } & 10 & 0.97 \\
\hline & & 15 & 1.16 \\
\hline & \multirow{2}{*}{ QH03 } & 12 & 1.15 \\
\hline & & 24 & 0.92 \\
\hline & QH04 & 7 & 1.2 \\
\hline & \multirow{2}{*}{ QH01 } & 3 & 1.13 \\
\hline & & 9 & 1.32 \\
\hline \multirow{5}{*}{ Qingshan syncline } & \multirow{2}{*}{ MY01 } & 17 & 0.89 \\
\hline & & 19 & 1.15 \\
\hline & \multirow{3}{*}{ MY03 } & 17 & 1.24 \\
\hline & & 19 & 1.13 \\
\hline & & 29 & 1.09 \\
\hline \multirow{2}{*}{ Bide syncline } & \multirow{2}{*}{3603} & 2 & 1.01 \\
\hline & & 6 & 1.01 \\
\hline \multirow{4}{*}{ Shuigonghe syncline } & \multirow{4}{*}{$\mathrm{J} 1402$} & 3 & 2.54 \\
\hline & & 5 & 2.54 \\
\hline & & 8 & 0.98 \\
\hline & & 16 & 2.51 \\
\hline
\end{tabular}


In general, for enclosing coal reservoirs throughout geologic history, as the degree of thermal evolution increases, so does the gas quantity and the reservoir pressure. However, the reservoir pressure change is complicated in the western Guizhou and eastern Yunnan regions, including the development of normal pressure as well as abnormally high pressure in the main tectonic units. Communication between the reservoir fluid and the outside environment over time led to the differences of leakage intensity in the reservoir pressure. For smaller pores and less fluid discharge, pore pressure would increase to abnormally high levels; in contrast, for larger pores with less fluid supply, pore pressure would decrease to abnormally low levels. Thus, the complex tectonic evolution of the region caused differential development of reservoir pressure. The ability of fluid to communicate with the outside environment created a complex stress state, with differences between both tectonic units and block sections in the same tectonic unit of the coal reservoir.

Four CBM wells were drilled in the Jinzhuping exploration region on the east wing of the Panguan syncline and the Liangshan exploration region on the west wing of the Panguan syncline (Fig. 9). The reservoir pressure of the Jinzhuping and Liangshan blocks is 6.6 MPa and 8.7-12.9 $\mathrm{MPa}$, respectively, and the calculated pressure coefficients of the two blocks are 1.2 and 1.0, respectively. Therefore, the coal reservoir of the Panguan syncline is generally a normal-supernormal pressure system. However, the Liangshan block on the west wing is mainly a normal pressure system and the Jinzhuping block on the east wing is a supernormal pressure system. Outcropping strata in the wings of the Panguan syncline include the Maokou Formation $\left(\mathrm{P}_{2 \mathrm{~m}}\right)$, the Emeishan Basalt Formation $\left(\mathrm{P}_{2 \beta}\right)$, the Longtan Formation $\left(\mathrm{P}_{31}\right)$, the Feixianguan Formation $\left(\mathrm{T}_{1 \mathrm{f}}\right)$, and the Yongningzhen Formation $\left(\mathrm{T}_{1 \mathrm{y}}\right)$. These strata are in direct contact with precipitation and surface water (Fig. 2). Their elevation is much higher than in the central basin; as a result, precipitation moves from the shallow rocks into the shaft of the syncline along weathering fractures. In the deep strata, the fracture extent and the runoff flow become weaker, causing confined water sealing for CBM, which makes the reservoir become over-pressurized.

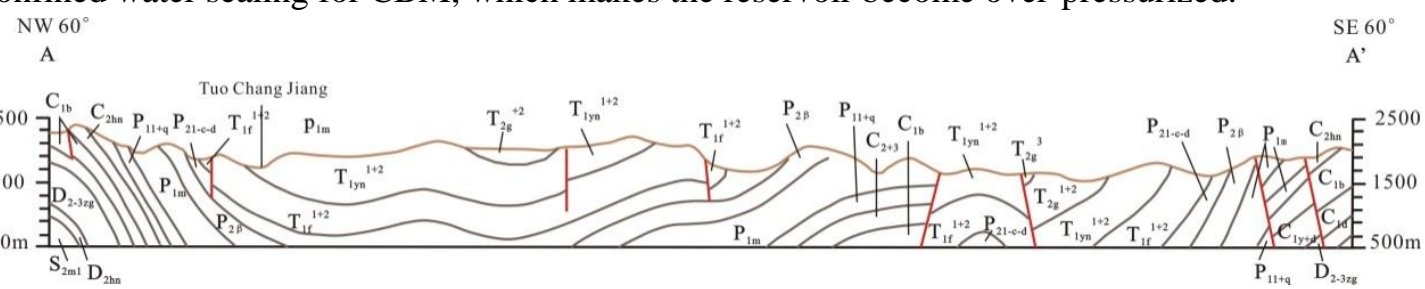

Fig.9.Structural section of the Panguan syncline and distribution of surface drainage (from Xu, 2011).

In the Panguan syncline, Upper Permian coal seams are characterized by middle to high coal rank and the coal rank increases to the east (Fig. 1), from fat coal to meager coal. This indicates that the thermal evolution degree of the coal seam in the east wing was significantly higher than in the west wing. The discharge in reservoir pressure and the stability of fluid energy are directly related to the enrichment degree of CBM. For instance, according to the measured ground stress data, the ground stress gradient of $2.8 \mathrm{MPa} / 100 \mathrm{~m}$ in the Jinzhuping block is higher than in the Liangshan block, where it is $2.18 \mathrm{MPa} / 100 \mathrm{~m}$. Similarly, the gas content of the Jinzhuping block $\left(14.8 \mathrm{~m}^{3} / \mathrm{t}\right)$ is higher than in the Liangshan block $\left(10.97 \mathrm{~m}^{3} / \mathrm{t}\right)$.

\subsection{Accumulation effect of regional coalbed methane}

Hydrothermal metal ores are widely distributed in the western Guizhou and eastern Yunnan regions (Gui and Wang, 2000;Wu et al., 2013); they include copper, zinc, gold, and antimony (Fig. 10). This indicates that the hydrothermal fluids flowed over a wide area, which corresponds well 
to the area of high coal rank.

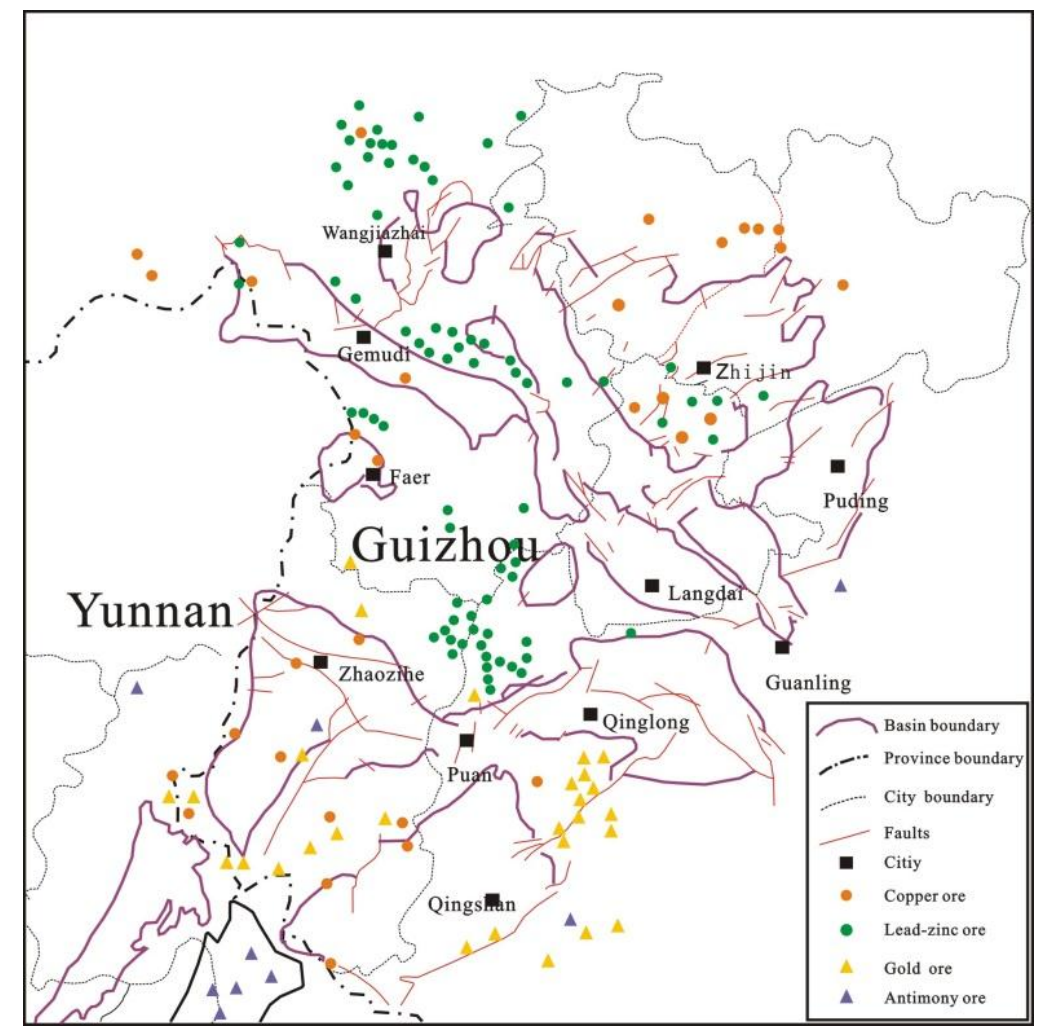

Fig.10. Distribution of hydrothermal metallic ore deposits.

Most of the study area is located on the southwest margin of the Yangtze platform with the Ziyun-Yadu and Guiyang-Huangping faults as boundaries. North of this boundary is the Qianbei platform and to the south is the Qiannan fault depression. The differences between these two tectonic units cause variations in the geothermal field from south to north; this also led to different accumulation conditions for coalbed methane. In the study area, according to the largest coal rank (results from simulation) in every basin occurred under plutonic metamorphism (Table 8), there is an obvious division between the area in which normal coal metamorphism occurred under the control of plutonic metamorphism and the area in which abnormal coal metamorphism occurred, controlled by both plutonic metamorphism and hydrothermal metamorphism (Fig. 11). There are no massive exposed igneous rocks in the anthracite area in northern, central and southern Guizhou Province; however, the presence of medium-low temperature endogenous metal deposits indicates that there may be a concealed igneous rock body. Magmatic hydrothermal activity is the leading factor affecting coal metamorphism and causing coal zonation (Wang, 1980). This study and previous research suggests that plutonic metamorphism was the regional background for coal metamorphism during the Late Permian in the western Guizhou and eastern Yunnan regions, onto which hydrothermal metamorphism effects were superimposed (Yang, 1982). 
Table 8. The largest coal ranks (results from simulation), which only occurred under plutonic metamorphism

\begin{tabular}{cc}
\hline Area & Largest coal rank $(\%)$ \\
\hline Laochang & 1.7 \\
\hline Enhong & 1.0 \\
\hline Panxian & 1.0 \\
\hline Gemudi & 1.8 \\
\hline Zhijin & 2.6 \\
\hline
\end{tabular}

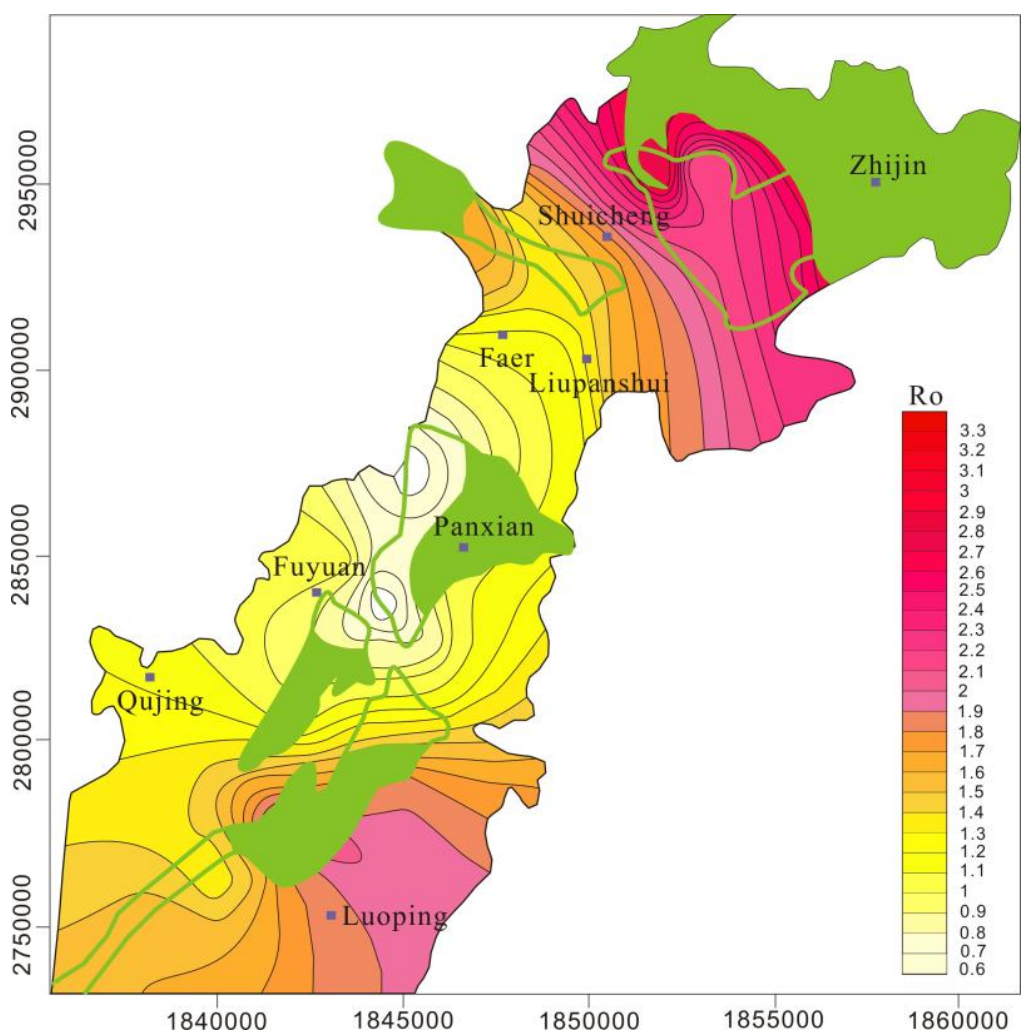

Fig.11. Coal metamorphism degree in the whole region

Green shadow region: abnormal coal metamorphism region, controlled by both plutonic metamorphism and hydrothermal metamorphism; the rest region: normal coal metamorphism region, controlled only by plutonic metamorphism

After Hercynian movement and before Indosinian movement, the intensity of tectonic movement was small, and the geothermal gradient during formation of the early and middle Triassic coal strata was also small, averaging $3.1^{\circ} \mathrm{C} / 100 \mathrm{~m}$. During the period of Indosinian and Yanshan movement, the average geothermal gradient in the upper Triassic and Jurassic strata increased to $4.2^{\circ} \mathrm{C} / 100 \mathrm{~m}$ with the increasing intensity of tectonic movement. During the Indosinian, the peak of the paleogeothermal gradient coincided with the peak of basin expansion, and during the Yanshan, it coincided with the peak of basin closure. These two phases corresponded to the two phases of hydrothermal fluid activity, which significantly influenced the accumulation of regional coalbed methane. The area to the north of the platform uplift is relatively closed and stranded, where the allocation conditions of hydrothermal fluid could provide more favorable conditions for the enrichment and accumulation of regional coalbed methane. 


\section{Conclusions}

Based on the geological characteristics of the hydrothermal fluid in the western Guizhou and eastern Yunnan regions, this study discussed the geological effects of hydrothermal fluids in the area. We developed a new perspective on hydrothermal activity in the regional strata and used it to analyze the process of enrichment and accumulation of coalbed methane.

Two stages of regional hydrothermal fluid activity occurred in the western Guizhou and eastern Yunnan regions. During the early stage, calcium fluid acted as the carrier, and during the later stage, it was replaced by siliceous fluid with a small amount of calcium fluid. The fluid flow of the first stage occurred during the Early Triassic to the middle period of the Late Jurassic; it was characterized by thermal cycling of hot water through the strata. The fluid temperature matched the temperature of the strata, and differences in the fluid temperature largely stem from the sedimentary burial depth. Fluid flow during the second stage was coincident with large-scale tectonic movement during the late period of Late Jurassic, and differences in fluid temperature were related to magmatic hydrothermal activities during the Yanshan. Because of the injection of deeply sourced high temperature hydrothermal fluid, the fluid temperatures were higher than the normal burial depth temperatures of the strata.

We propose three geological mechanisms by which hydrothermal fluids affected the enrichment and accumulation of coalbed methane: stimulation for hydrocarbon generation, transformation for physical properties and fluid supercharging. Thermal fluids advance the degree of thermal evolution, increase gas generation and the adsorption capacity of coal, and induce high intensity generation and migration of coalbed methane. This produces dense swarms of tubular pores, which increase the porosity. The invasion, derivation, extrusion and wedging effects of thermal fluids break the coal body, improve its permeability and are coincident with tectonic stress. The intensity of fluid effects and the differential leakage of fluid pressure in a coal reservoir are major factors that control pressure development in a gas reservoir. The relatively closed and stranded thermal fluid environment of coal measure strata is conducive to the formation of high pressure in the coalbed methane system.

In the western Guizhou and eastern Yunnan strata, the peak of paleogeothermal gradient of the hot water stage coincided with the peak of basin expansion, and the peak of the paleogeothermal gradient during the deeply sourced high temperature fluid stage coincided with the peak of basin closure. These two phases corresponded to the two phases of thermal fluid activity, which significantly influenced the accumulation of regional coalbed methane. The area north of the platform uplift is relatively closed and stranded environment, in which geological configuration of hydrothermal fluids made favorable conditions for the enrichment and accumulation of coalbed methane.

\section{Acknowledgements}

This research was financially supported by the National Natural Science Foundation of China (Grant No. 41272175), the State Key Program of the National Natural Science of China (Grant No. 41530314), China National Major Science Project (Grant No. 2016ZX05044), National Science Foundation for Distinguished Young Scholars of China (Grant No. 41502157). 


\section{References}

Bercovici A., Cui Y., Forel M.B., et al. 2015. Terrestrial paleoenvironment characterization across the Permian-Triassic boundary in South China[J]. Journal of Asian Earth Sciences, 98(In Press):225-246.

Barker C.E, Bone Y., Lewan M.D., 1998. Fluid inclusion and vitrinite-reflectance geothermometry compared to heat-flow models of maximum paleotemperature next to dikes, western onshore Gippsland Basin, Australia[J]. International Journal of Coal Geology, 37(s 1-2):73-111.

Boyd N.K. and Smithson S.B., 1993 Moho in the Archean Minnesota gneiss terrane: Fossil, alteration, or layered intrusion?[J]. Geology, 21(12):1131.

Cromie P.W. and Zaw K., 2003. Geological setting, nature of ore fluids and sulphur isotope geochemistry of the Fu Ning Carlin-type gold deposits, Yunnan Province, China[J]. Geofluids, 3(2):133-143.

Copard Y., Disnar J.R., Becq-Giraudon J.F., et al., 2000. Evidence and effects of fluid circulation on organic matter in intramontane coalfields (Massif Central, France)[J]. International Journal of Coal Geology, 44(1):49-68.

Cooper J.R., Crelling J.C., Rimmer S.M. and Whittington A.G., 2007. Coal metamorphism by igneous intrusion in the Raton Basin, CO and NM: Implication for generation of volatiles. International Journal of Coal Geology 71, $15-27$.

Dai S.F., Zhang W., Ward C.R., et al., 2013. Mineralogical and geochemical anomalies of late Permian coals from the Fusui Coalfield, Guangxi Province, southern China: Influences of terrigenous materials and hydrothermal fluids[J]. International Journal of Coal Geology, 105(1):60-84.

Ding S.L., Zhu J.G., Zhen B.P., et al., 2011. Characteristics of high rank coalbed methane reservoir from the Xiangning Mining Area, Eastern Ordos Basin, China. Energy Exploration and Exploitation 29(1), 33-48.

Dubessy J., 2004. Fluid inclusions in sedimentary basins: Theoretical basis, diagrams, analytical techniques[J]. Acta Petrologica Sinica, 20(6): 1301-1318

Fu H, Wang X, Zhang L, et al. Investigation of the factors that control the development of pore structure in lacustrine shale: A case study of Block X in the Ordos Basin, China[J]. Journal of Natural Gas Science \& Engineering, 2015, 26:1422-1432.

Gamson P.D., Beamish B.B., Johnson D.P., 1998. Effect of coal microstructure and secondary mineralization on methane recovery. Geological Special Publication 199, 165-179.

Gao D., Qin Y., Yi T.S., et al., 2009. Geological Condition, Exploration and Exploitation Strategy of Coal-bed Methane Resources in Guizhou, China[J]. Coal Geology of China, 21(3): 20-23(in Chinese with English abstract).

Gui B.L. and Wang C.D., 2000. Structural characteristics of coalbed methane in East Yunnan and West Guizhou area. Yunnan Geology, 19(4), 321-351(in Chinese with English abstract).

Gui B.L., 1999. Geology characteristics and enrichment controlling factors of Coalbed Methane in Liupanshui region. Acta Petrolei Sinica, 20(3), 31-37(in Chinese with English abstract).

Gu C.L., 2002. Geological characteristics and prospect evaluation on coal-seam gas in East Yunnan and West Guizhou areas. Xinjiang Petroleum Geology 23, 106-111(in Chinese with English abstract).

Grafka O., Marynowski .L, Simoneit B.R.T., 2014. Phenyl derivatives of polycyclic aromatic compounds as indicators of hydrothermal activity in the Silurian black siliceous shales of the Bardzkie Mountains, Poland. International Journal of Coal Geology, 139:142-151.

Hunt, J.M., 1990. Generation and migration of petroleum from abnormally pressured fluid compartments. AAPG Bull. 74, 1-12.

Irmer G., 2002. Isotopes of $\mathrm{C}$ and $\mathrm{O}$ in CO2: a Raman study using gas standards and natural fluid inclusions. Acta Universitatis Carolinae - Geologica, 46. 
Jones J.M. and Creaney S., 1977. Optical character of thermally metamorphosed coals of northern England[J]. Journal of Microscopy, 109(1):105-118.

Kelly J., Parnell J., Chen H.H., 2000. Application of fluid inclusions to studies of fractured sandstone reservoirs[J]. Journal of geochemical exploration, 69(9): 705-709.

Karacan C.O. and Okandan E., 2001. Adsorption and gas transport in coal microstructure: investigation and evaluation by quantitative X-ray CT imaging. Fuel 80, 509-520,

Law B.E. and Dickinson W.W., 1985. Conceptual model for origin of abnormally pressured gas accumulations in low-permeability reservoirs. AAPG Bull. 69, 1295-1304.

Lascola R, Zeigler K E, Mcwhorter C S, et al. Isotopic hydrogen analysis via conventional and surface-enhanced fiber optic Raman spectroscopy[J]. Office of Scientific \& Technical Information Technical Reports, 2004, 5586.

Li L., Wei C., Qi Y., et al., 2014.Coalbed methane reservoir formation history and its geological control at the Shuigonghe Syncline[J]. Arabian Journal of Geosciences, 8(2):619-630.

Li S., Tang D.Z., Pan Z.J., et al. 2014. Influence and control of coal facies on physical properties of the coal reservoirs in Western Guizhou and Eastern Yunnan, China. International Journal of Oil Gas \& Coal Technology, $8(2), 221-234$

Li S., Tang D.Z., Pan Z.J., et al. 2015. Evaluation of coalbed methane potential of different reservoirs in western Guizhou and eastern Yunnan, China. Fuel, 139:257-267.

Marfil R., Rossi C., Goldstein R.H., et al., 2002. Fluid inclusions record thermal and fluid evolution in reservoir sandstones, Khatatba Formation, Western Desert, Egypt: a case for fluid injection.[J]. AAPG Bulletin, 86(10):1773-1779.

Michael K. and Bachu S., 2001. Fluids and pressure distributions in the foreland-basin succession in thewest-central part of the Alberta Basin, Canada: Evidence for permeability barriers and hydrocarbon generation and migration. AAPG Bull. 85, 1231-1252.

Mutter J.C. and Carton H.D., 2013. The Mohorovicic discontinuity in ocean basins: Some observations from seismic data. Tectonophysics, 609(1):314-330.

Qin Y., Xiong M.H., Yi T.S., et al. 2008. On Unattached Multiple Superposed Coalbed—Methane System: in a Case of the Shuigonghe Syncline, Zhijin-Nayong Coalfield, Guizhou. Geological Review, 54(1), 65-70(in Chinese with English abstract).

Sweeney J J, Burnham A K. Evaluation of a simple model of vitrinite reflectance based on Chemical kinetics[J]. Aapg Bulletin, 1990, 74(10):1559-1570.

Song X.Y., Zhang C.J., Hu R.Z., et al. 2005. Genetic links of magmatic deposits in the Emeishan large igneous province with dynamic of mantle plume. Journal of Mineralogy \& Petrology, 25(4): 35-44.

Su X.B., Zhang L.P., Zhang R.L., 2003. The abnormal pressure regime of the Pennsylvanian No. 8 coalbed methane reservoir in Liulin-Wupu District, Eastern Ordos Basin, China. Int. J. Coal Geol. 53, 227-239.

Sun Y.Z., 2003. Petrologic and geochemical characteristics of "barkinite" from the Dahe mine, Guizhou Province, China. International Journal of Coal Geology 56, 269-276.

Solano-Acosta W., Mastalerz M., Schimmelmann A., 2007. Cleats and their relation to geologic lineaments and coalbed methane potential in Pennsylvanian coals in Indiana. International Journal of Coal Geology 72 , 187-208.

Tian W.J., 2008. Coal- bearing property analysis of Late Permian Coalfields in Guizhou Province. Coal Geology of China, 20(4), 21-23 (in Chinese with English abstract).

Tao S., Tang D.Z., Qin Y., et al. 2010. Analysis on thermal history of coal strata of typical mining areas in western Guizhou and eastern Yunnan. Coal Geology \& Exploration, 38(6),17-21(in Chinese with English abstract). 
Tobin R.C. and Claxton B.L. 2000. Multidisciplinary thermal maturity studies using vitrinite reflectance and fluid inclusion microthermometry: A new calibration of old techniques[J]. Aapg Bulletin American Association of Petroleum Geologists, 84(10):1647-1665.

Wu Y, Qin Y, Wang A, et al., 2013. Geochemical anomaly and the causes of transition metal accumulations in late Permian coal from the eastern Yunnan-western Guizhou region. Journal of China University of Mining\&Technology, 23(1):105-111.

Xie X.N., Jiao, J.J., Tang Z.H., et al., 2003. Evolution of abnormally low pressure and its implications for the hydrocarbon system in the southeast uplift zone of Songliao basin, China. AAPG Bull. 87, 99-119.

Xu H., Tang D., Zhang J., et al., 2011. Factors affecting the development of the pressure differential in Upper Paleozoic gas reservoirs in the Sulige and Yulin areas of the Ordos Basin, China[J]. International Journal of Coal Geology, 85(1):103-111.

Xu H.J., Sang S.X., Yi T.S., et al., 2014. Mechanism of Buried Depth and In-Situ Stress for Coal Reservoir Permeability in Western Guizhou. Earth Science (Journal of China University of Geosciences), 39(11):1607-1616.(in Chinese with English abstract).

Yuan K, Chen B T, Xing-He Y U, et al. Basin modeling techniques and application of the BasinMod software[J]. Sedimentary Geology \& Tethyan Geology, 2010, 30(2):55-60. (in Chinese with English abstract)

Yang Q., Ren D., Pan Z.G., 1982. Preliminary Invesitigation on the metamorphism of Chinese Coals. International Journal of Coal Geology, 2(1):31-48(in Chinese with English abstract).

Zhou Y., Bohor B.F., Ren Y., 2000. Trace element geochemistry of altered volcanic ash layers (tonsteins) in Late Permian coal-bearing formations of eastern Yunnan and western Guizhou Provinces, China [J]. International Journal of Coal Geology, 44(s 3-4):305-324. 